\title{
Heparin regulates B6FS cell motility through a FAK/actin cytoskeleton axis
}

\author{
KALLIRROI VOUDOURI ${ }^{1}$, DRAGANA NIKITOVIC ${ }^{1}$, AIKATERINI BERDIAKI ${ }^{1}$, DIONYSIOS J. PAPACHRISTOU ${ }^{2}$, \\ JOHN TSIAOUSSIS ${ }^{1}$, DEMETRIOS A. SPANDIDOS ${ }^{3}$, ARISTIDES M. TSATSAKIS ${ }^{4}$ and GEORGE N. TZANAKAKIS ${ }^{1}$ \\ ${ }^{1}$ Laboratory of Anatomy-Histology-Embryology, School of Medicine, University of Crete, Heraklion 71003; \\ ${ }^{2}$ Laboratory of Anatomy-Histology-Embryology, School of Medicine, University of Patras, Patras 23001; \\ ${ }^{3}$ Laboratory of Virology, and ${ }^{4}$ Laboratory of Toxicology, School of Medicine, University of Crete, Heraklion 71003, Greece
}

Received May 4, 2016; Accepted August 11, 2016

DOI: $10.3892 /$ or.2016.5057

\begin{abstract}
Soft tissue sarcomas are rare, heterogeneous tumors of mesenchymal origin with an aggressive behavior. Heparin is a mixture of heavily sulfated, linear glycosaminoglycan (GAG) chains, which participate in the regulation of various cell biological functions. Heparin is considered to have significant anticancer capabilities, although the mechanisms involved have not been fully defined. In the present study, the effects of unfractionated heparin (UFH) and low-molecular-weight heparin (LMWH) on B6FS fibrosarcoma cell motility were examined. Both preparations of heparin were shown to both enhance B6FS cell adhesion $(\mathrm{p}<0.01$ and $\mathrm{p}<0.05)$, and migration $(\mathrm{p}<0.05)$, the maximal effect being evident at the concentration of $10 \mu \mathrm{g} / \mathrm{ml}$. The utilization of FAK-deficient cells demonstrated that the participation of FAK was obligatory for heparin-dependent fibrosarcoma cell adhesion $(\mathrm{p}<0.05)$. The results of confocal microscopy indicated that heparin was taken up by the B6FS cells, and that UFH and LMWH induced F-actin polymerization. Heparitinase digestion demonstrated that the endogenous heparan sulfate (HS) chains did not affect the motility of the B6FS cells ( $p>0.05$, not significant). In conclusion, both UFH and LMWH, through a FAK/actin cytoskeleton axis, promoted the adhesion and migration of B6FS fibrosarcoma cells. Thus, our findings indicate that the responsiveness of fibrosarcoma cells to the exogenous heparin/HS content of the cancer microenvironment may play a role in their ability to become mobile and metastasize.
\end{abstract}

Correspondence to: Dr George N. Tzanakakis, Laboratory of Anatomy-Histology-Embryology, School of Medicine, University of Crete, Heraklion 71003, Creece

E-mail: tzanakak@med.uoc.gr

Abbreviations: GAG, glycosaminoglycan; UFH, unfractionated heparin; LMWH, low-molecular-weight heparin; FN, fibronectin; FAK, focal adhesion kinase

Key words: heparin, fibrosarcoma, adhesion, migration, fibronectin, focal adhesion kinase

\section{Introduction}

Soft tissue sarcomas are rare tumors of mesenchymal origin with a frequent ability for distant metastasis (1). Fibrosarcomas, tumors belonging to this group, specifically originate from muscular fibrous tissues, fascia and tendons (2). Annually, fibrosarcomas represent $3 \%$ of all soft tissue sarcomas and $1 \%$ of new cancer cases diagnosed in the United States and Europe $(2,3)$. The treatment of fibrosarcomas is mainly surgical and must be individualized due to the rarity and pleiotrophy of these tumors $(2,3)$.

Unfractionated heparin (UFH) is a mixture of heavily sulfated, linear glycosaminoglycan (GAG) chains, which participate in the regulation of various cell biological functions (4), including the modulation of growth factor activities (5), the inhibition of heparanase $(5,6)$ and changes in extracellular matrix (ECM) composition (7). Its size ranges from 3 to $30 \mathrm{kDa}$, with chains in the $12-15 \mathrm{kDa}$ size range most commonly used. On the other hand, low-molecular-weight heparin (LMWH) consists of LMW fragments produced by the depolymerization (enzymatic or chemical) of UFH, which yields chains that are $<18$ saccharide units long (8). UFH and LMWH have been extensively used over the years as anticoagulant agents for the prevention of thromboembolism in cancer patients (9-12). The long-term utilization of heparin preparations as anti-coagulants has led to the understanding that UFH and LMWH positively affect the survival of cancer patients (9, 13-15). Moreover, the effects of high-molecular-weight haparin (HMWH) and LMWH were found to be discrete. Thus, according to clinical data, patients who had been treated with LMWH in order to minize the risk of thrombosis have an improved survival (3 months) as compared to those treated with UFH (15), and an increased long-term survival period (16). Specifically, the anticancer effect of LMWH has been ascribed to its inhibition of angiogenesis via the cellular release of tissue factor pathway inhibitor in endothelial cells (17) or its expression by cancer cells (18). The anticancer effect of heparin may be due to its nonanticoagulant derivatives (19), and novel heparin therapeutical approaches are proposed. Of note, heparin has been found to inhibit the proliferation of various normal cell types, including vascular smooth muscle cells, mesanglial cells, fibroblasts and epithelial cells (20-23). Likewise, the majority of studies 
have indicated that heparin inhibits cancer cell growth $(24,25)$, even though exceptions to the rule have been reported $(26,27)$. Moreover, using the B6FS fibrosarcoma cell model, we have previously demonstrated that heparin attenuates the growth ability of these cells (28).

By contrast, some early studies have suggested that heparin enhances the spread of cancer cells to other organs and tissues (29-31). Different mechanisms of action of heparin have been proposed. Thus, LMWH was found to inhibit the proliferation, migration, invasion and lung metastatic ability of HT1080 fibrosarcoma cells through a blockade of the RAGE axis (32). Chalkiadaki et al demonstrated that UFH, by activating p53/focal adhesion kinase (FAK)-dependent signaling, modulated melanoma cell adhesion and migration (33). The same authors also demonstrated that LMWH inhibited the ability of melanoma cells to adhere and to migrate, utilizing a protein kinase $\mathrm{C}(\mathrm{PKC}) \alpha / \mathrm{c}$-Jun $\mathrm{N}$-terminal kinase (JNK) signaling axis and resulting in actin cytoskeletal changes (34).

Fibronectin (FN) is a key ECM component that affects cell attachment and migration (35). Importantly, FN expression has been shown to correlate with aggressive cancer progression (35-37). Fibrosarcoma cells have been demonstrated to specifically adhere to the FN substrate $(38,39)$. In this study, we investigated the putative biological roles of UFH and LMWH in the migratory and adhesive properties of B6FS fibrosarcoma cells.

\section{Materials and methods}

Reagents. UFH and LMWH were supplied by Sigma (St. Louis, MO, USA). Stock solutions of $10 \mathrm{mg} / \mathrm{ml}$ were prepared by dissolving heparin in sterile, RNase- and DNase-free DEPC water (Cayman Chemical Co., Ann Arbor, MI, USA). Human plasma FN (1 mg/ml) was obtained by Millipore Corp. (Billerica, MA, USA). RPMI medium and penicillin-streptomycin were obtained from Biosera (Sussex, UK) and gentamycin was supplied by Invitrogen Life Technologies (Carlsbad, CA, USA). Fetal bovine serum (FBS) was purchased by Gibco Life Technologies (Carlsbad, CA, USA). Fluorescein isothiocyanate (FITC)-conjugated unfractionated heparin (referred to as FITC-Heparin) was obtained from Invitrogen Life Technologies. D-[6-3H(N)]glucosamine hydrochloride was supplied by DuPont de Nemours (Dreiech, Germany). Heparin lyase II (heparinase II, no EC number) from Flavobacterium heparinum, chondroitinase AC II from Arthrobacter aurescens (EC 4.2.2.5), proteinase $\mathrm{K}$ and $2 \mathrm{X}$ crystallized papain (EC 3.4.22.2) were obtained from Sigma Chemical Co. (St. Louis, MO, USA). Heparin lyases I and III from Flavobacterium heparinum (EC 4.2.2.7 and EC 4.2.2.8, respectively), chondroitinase ABC from Proteus vulgaris (EC 4.2.2.4), keratanase II and the anti-heparitinase stubs antibody clone (3G10) were from Seikagaku Kogyo Co. (Tokyo, Japan).

Cell culture conditions and transfection with short intefering RNA(siRNA).In this study we used the B6FS human fibrosarcoma cell line (40). The cells were obtained from the Cell Bank of the Karolinska Institute, Stockholm, Sweden and were a kind gift from Dr. Anders Hjerpe (Karolinska Institute). The cells were cultured at $37^{\circ} \mathrm{C}$ and humidity $5 \% \mathrm{CO}_{2}$ in RPMI supplemented with $10 \%$ FBS and antimicrobial agents (100 IU/ml penicillin,
$100 \mu \mathrm{g} / \mathrm{ml}$ streptomycin and $0.5 \%$ gentamycin). All experiments were conducted under serum-free conditions; specifically after $24 \mathrm{~h}$ of serum starvation, the cells were treated with UFH and LMWH $(10 \mu \mathrm{g} / \mathrm{ml}$ and $30 \mu \mathrm{g} / \mathrm{ml})$ for $48 \mathrm{~h}$.

The B6FS cells $(450,000$ cells per T25 flask) were incubated with siRNA (100 nM) specific for the FAK gene (siFAK), as previously described by Hong et al (41) and with siRNA negative control sequences (siScramble) for $6 \mathrm{~h}$. Specific RNA (Invitrogen Life Technologies) and Lipofectamine ${ }^{\circledR} 2000$ (Invitrogen Life Technologies) (1/50 $\mu \mathrm{l}$ medium) were added to Opti-MEM $^{\odot}$ (Invitrogen Life Technologies) for $5 \mathrm{~min}$ at room temperature. In continuation, diluted Lipofectamine 2000 was mixed with the siRNA for 20 min to induce the formation of liposome-siRNA complexes. The medium containing siRNA or siScramble was removed after $6 \mathrm{~h}$ of incubation and fresh RPMI 0\% FBS medium supplemented with antibiotics was added. The cells were harvested for the respective experiments, after $48 \mathrm{~h}$ of culture.

Western blot analysis. After $48 \mathrm{~h}$ of respective treatments, the harvested B6FS cells were lysed with RIPA buffer and electrophoresed on an $8 \%$ polyacrylamide gel. Protein bands were transferred onto nitrocellulose membrane in $10 \mathrm{nM}$ CAPS, $\mathrm{pH} 11$ and $10 \%$ methanol. All membranes were blocked and incubated overnight at $4^{\circ} \mathrm{C}$ with PBS containing $0,1 \%$ Tween-20 and $5 \% \mathrm{v} / \mathrm{v}$ low fat milk powder. The respective membranes were incubated with the primary antibodies diluted in PBS containing $0,1 \%$ Tween and $1 \% \mathrm{v} / \mathrm{v}$ low fat milk powder, for $1 \mathrm{~h}$ at room temperature. The following primary antibodies were used: p-FAK (1:200; MAB1141; Millipore Corp.), FAK (1:200; sc-557; Santa Cruz Biotechnology, Inc., Santa Cruz, CA, USA), nuclear factor- $\kappa \mathrm{B}(\mathrm{NF}-\kappa \mathrm{B})$ p65 subunit (1:200; (sc-109; Santa Cruz Biotechnology, Inc.) and $\beta$-actin (1:2,500; MAB1501; Millipore Corp.). The immune complexes were detected by peroxidase-conjugated anti-mouse, anti-goat and anti-rabbit secondary antibodies (1:10,000; Millipore Corp.), using SuperSignal West Pico Chemiluminescent substrate (Pierce Biotechnology, Inc., Rockford, IL, USA).

Real-time PCR. For real-time PCR, mRNA was isolated using TRIzol reagent (Invitrogen Life Technologies) according to manufacturer's instructions. RNA $(1 \mu \mathrm{g})$ was used for cDNA synthesis, using the Takara reverse transcription reagent kit (Takara Bio, Dalian, China). Real-time PCR was performed using the Mx300P cycler (Stratagene; Agilent Technologies, Inc., Santa Clara, CA, USA). The KAPA SYBR ${ }^{\circledR}$ FAST Universal qPCR kit (Kapa Biosystems, Inc., Wilmington, MA, USA) was used for real-time PCR reactions in a total volume of $20 \mu \mathrm{l}$ and with suitable specific gene primers (Table I). The PCR conditions used for amplification were: $94^{\circ} \mathrm{C}$ for $15 \mathrm{~min}$ followed by 40 cycles at $94^{\circ} \mathrm{C}$ for $20 \mathrm{sec}, 55^{\circ} \mathrm{C}$ for $30 \mathrm{sec}$ and $72^{\circ} \mathrm{C}$ for $30 \mathrm{sec}$, followed by $72^{\circ} \mathrm{C}$ for $10 \mathrm{~min}$. Standard curves were run and produced a linear plot of threshold cycle $(\mathrm{Ct})$ against dilution (log). Gene levels were quantified according to the concentrations of a standard curve and are presented as arbitrary units. GAPDH was used as a housekeeping gene, for comparison between samples.

Determination of heparan sulfate $(H S)$ content. The determination of the HS content was carried out as previously described by 
Table I. Primer sequences used for real-time PCR.

\begin{tabular}{ll}
\hline Gene & \multicolumn{1}{c}{ Primer sequences } \\
\hline FAK & F: 5'-GTGCTCTTGGTTCAAGCTGGAT-3' \\
& R:5'-ACTTGAGTGAAGTCAGCAAGATGTGT-3' \\
GAPDH & F: 5'-GGAAGGTGAAGGTCGGAGTCA-3' \\
& R: 5'-GTCATTGATGGCAACAATATCCACT-3'
\end{tabular}

FAK, focal adhesion kinase. F, forward, R, reverse.

Karamanos et al (42). Briefly, in order to determine the amount of HS production by the B6FS cells, we performed metabolic labeling of GAGs by supplementing the cell cultures with $\mathrm{D}-[6-3 \mathrm{H}(\mathrm{N})]$ glucosamine hydrochloride $(10 \mu \mathrm{Ci} / \mathrm{ml})$ during the period of $16 \mathrm{~h}$ prior to the respective harvesting time. Upon the termination of the incubation period, the cells were harvested and cell-associated proteoglycans (PGs) were extracted with $50 \mathrm{mM}$ Tris- $\mathrm{HCl}$, pH 8.0, containing 1\% (v/v) Triton X-100 and $0.1 \%(\mathrm{w} / \mathrm{v}) \mathrm{NaCl}$ and the following proteinase inhibitors: phenylmethanesulfonyl flouride, benzamidine hydrochloride and hexanoic acid at final concentrations of 2,5 and $50 \mathrm{mM}$, respectively. The collected conditioned medium was concentrated to 1:100 of its original volume on an YM-10 membrane (Amicon/Millipore). The PGs were then precipitated by the addition of 4 vol. of $95 \%(\mathrm{v} / \mathrm{v})$ ethanol containing $2.5 \%(\mathrm{w} / \mathrm{v})$ sodium acetate with $40 \mu \mathrm{l}$ chondroitin sulfate (CSA; $0.2 \mathrm{mg} / \mathrm{l}$ ) added as a carrier. Following centrifugation $(11,000 \mathrm{x} \mathrm{g}$ for $10 \mathrm{~min}$ at $25^{\circ} \mathrm{C}$ ), the precipitates of PGs were digested with $2 \mathrm{U} / \mathrm{ml}$ proteolytic enzyme papain in $100 \mathrm{mM}$ phosphate buffer (pH 7.0) at $65^{\circ} \mathrm{C}$ for $60 \mathrm{~min}$. The GAGs liberated in this manner were precipitated by the addition of $10 \mathrm{vol} .1 \%(\mathrm{w} / \mathrm{v})$ cetylpyridium chloride (CPC) and centrifuged at $10,000 \mathrm{x} \mathrm{g}$ for $10 \mathrm{~min}$. The pellets obtained were dissolved in $500 \mu \mathrm{l}$ of $60(\mathrm{v} / \mathrm{v})$ propanol-1 containing $0.4 \%(\mathrm{w} / \mathrm{v})$ CPC. The liberated GAGs were reprecipitated by the addition of 6 vol. of 95\% (v/v) ethanol containing 2.5\% (w/v) sodium acetate. The precipitates were then washed with ethanol and allowed to dry. For the identification of galactosaminoglycans (GalAGs)., i.e., chondroitin sulfate (CS) and/or dermatan sulfate (DS), the GAG preparation was dissolved in water and digested with an equi-unit mixture $(0.2 \mathrm{U} / \mathrm{ml})$ of chondroitinases $A B C$ and AC II. Aliquots from the supernatant were analyzed by reversed polarity high-performance capillary electrophoresis (HPCE), as previously described (42). The determination of HS was carried out in the GAG preparations which were digested with heparin lyases I, II and III in combination $(0.05 \mathrm{U} / \mathrm{ml})$ in $20 \mathrm{mM}$ acetate buffer, $\mathrm{pH} 7.0$, containing $1 \mu \mathrm{mol}$ calcium acetate at $37^{\circ} \mathrm{C}$ for $90 \mathrm{~min}(43)$. In all cases, the amount of GAGs was determined from the integrated peak area of the GAG-derived $\Delta$-disaccharides.

$H S$ digestion. Heparitinase treatments were performed for the digestion of B6FS cellHS chains, as previously described $(24,26)$. In brief, cells seeded in 24-well plates were serum-starved for $24 \mathrm{~h}$ and then treated with heparitinase $(0.001 \mathrm{U} / \mathrm{ml})$ for 24 and $48 \mathrm{~h}$ in $0 \%$ FBS medium. The cell extracts treated with heparitinase were electrophoresed on $8 \%$ polyacryl- amide Tris/glycine gels and transferred onto nitrocellulose membranes. After blocking, the membranes were incubated for $1 \mathrm{~h}$ at room temperature with primary antibodies [mouse anti-heparitinase stubs antibody (clone 3G10; 1:500; CF500913; Seigakagu, Tokyo, Japan); goat anti-actin (1:200; sc-1616; Santa Cruz Biotechnology, Inc.) and mouse anti-CSA (1:200; C8035; Sigma)]. The immune complexes were detected following incubation with peroxidase-conjugated anti-goat or anti-mouse antibody, 1:4,000 or 1:2,000, respectively, with the SuperSignal West Pico Chemiluminescent substrate (Pierce Biotechnology, Inc.)

Cell adhesion assay. For the cell attachment assay, we used cells transfected with siFAK or cells treated with UHF and LMWH (for $48 \mathrm{~h}$ ). The cells were detached with $5 \mathrm{mM}$ PBS/EDTA. In continuation 5,000 cells/well were seeded onto a flat-bottom 96-well black plate. The bottom of the wells was coated with FN $(5 \mu \mathrm{g} / \mathrm{ml})$ for $1 \mathrm{~h}$ at $37^{\circ} \mathrm{C}$. BSA $1 \%$ (30 min at room temperature) was added for the blocking of non-specific binding sites. The cells were allowed to adhere for $30 \mathrm{~min}$ at $37^{\circ} \mathrm{C}$. The number of attached cells was determined using the CyQUANT fluometric assay (Molecular Probes; Invitrogen Life Technologies) according to the manufacturer's instructions.

Cell migration assay. To investigate the motility of cells, 24-well plates were used. Cells $(60,000$ cells/well) were seeded for $24 \mathrm{~h}$ in RPMI 10\% FBS and subsequently treated (as described above) for $48 \mathrm{~h}$. The cell stroma was wounded by scratching with a sterile $10 \mu \mathrm{l}$ pipette tip. The detached cells were washed twice by using fresh RPMI (serum-free). The wound closure was monitored at 0 and $6 \mathrm{~h}$ using a digital camera (Canon Inc., Tokyo, Japan) connected to a microscope (Leica, Mannheim, Germany). The quantification of the wound area was measured using Image J software.

Heparin internalization assay. The B6FS cells were seeded onto a 96-well plate in RPMI supplemented with $10 \%$ FBS for $24 \mathrm{~h}$ incubation and subsequently, FITC-Heparin was added at 1 and $10 \mu \mathrm{g} / \mathrm{ml}$ for $24 \mathrm{~h}$, in serum-free RPMI. Following this incubation, FITC-Heparin was removed and the cells were gently washed with RPMI ( $0 \%$ FBS). The concentration and the incubation times were chosen selected following optimization experiments (data not shown). FITC-Heparin internalization was visualized under a fluorescence microscope utilizing Leica DM2500 to acquire images.

Immunofluorescence. The B6FS cells were seeded onto glass coverslips into 24 -well plates $(65,000$ cells/well) and incubated with $10 \%$ FBS RPMI for $24 \mathrm{~h}$. Following $24 \mathrm{~h}$ of serum starvation, the cells were treated with UFH and LMWH for $48 \mathrm{~h}$. Subsequenlty, the cells were fixed in 5\% formldehyde and 2\% sucrose in PBS (incubation for $10 \mathrm{~min}$ at room temperature). Following 3 washes with PBS, Triton X permeabilizing agent was appled for $10 \mathrm{~min}$ at room temperature and washed prior to the addition of fluorescent phalloidin (1:100; Molecular Probes; Invitrogen Life Technologies) for $20 \mathrm{~min}$ in the dark. Fluorescent phalloidin was used for the detection of actin filaments. TO-PRO-3 (T3605; Molecular Probes/Thermo Fisher Scientific, Waltham, MA, USA) was then used for the nuclear staining (20 $\mathrm{min}$ in the dark). The coverslips were placed 

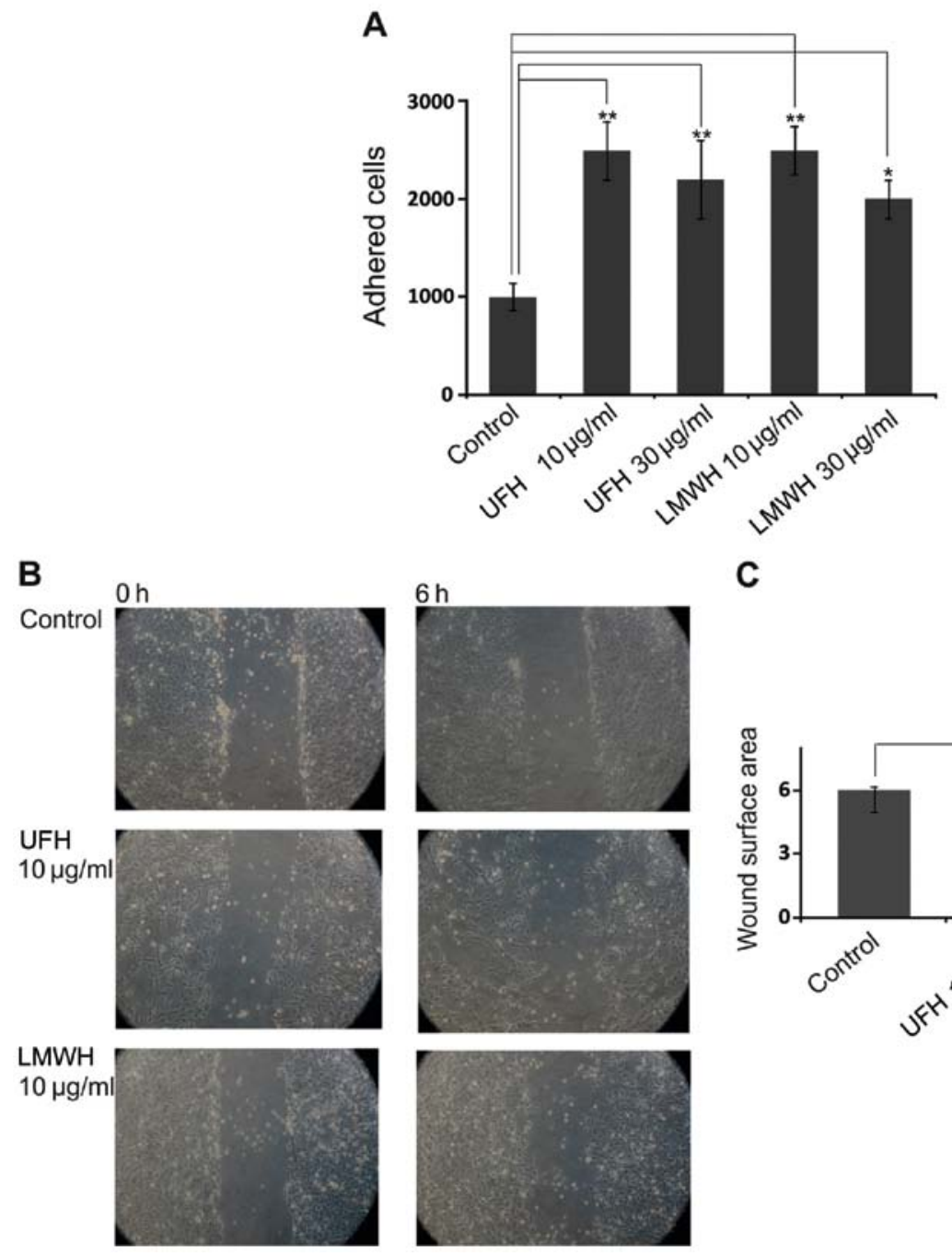

\section{C}

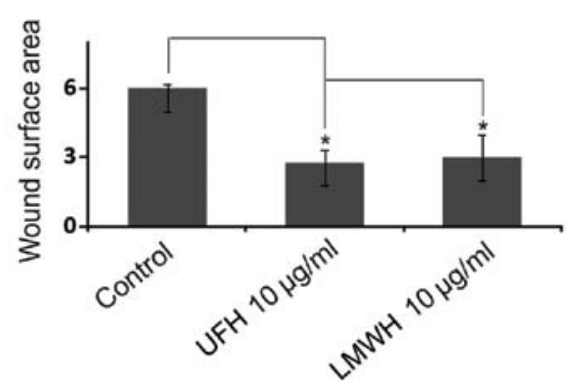

Figure 1. Effect of unfractionated heparin (UFH) and low-molecular-weight heparin (LMWH) on B6FS cell adhesion and migration. (A) B6FS cells were treated with UFH and LMWH $(10 \mu \mathrm{g} / \mathrm{ml})$ for $48 \mathrm{~h}$ prior to harvesting and reseeding for $1 \mathrm{~h}$ on 96 -well plates coated with fibronectin. The number of attached cells was determined using the fluometric CyQUANT assay kit; (B) B6FS cells were treated with UFH and LMWH $(10 \mu \mathrm{g} / \mathrm{ml})$ for $48 \mathrm{~h}$ prior to wounding. The cells were allowed to migrate for $6 \mathrm{~h} ;(\mathrm{C})$ the wound closure was monitored at 0 and $6 \mathrm{~h}$ using a digital camera connected to microscope. The quantification of the wound area was measured by using ImageJ software. The results represent the average of 3 separate experiments in triplicate. The means \pm standard error of the mean are plotted. ${ }^{*} \mathrm{p}<0.05$ and ${ }^{* *} \mathrm{p}<0.01$, indicate statistically significant differences.

onto slides using glycerol and images were collected using a laser-scanning spectral confocal microscope (TCS SP2; Leica), LCS Lite software (Leica) and a 63 Apochromat 1.40 numerical aperture oil objective.

Statistical analysis. Statistical significance was evaluated by one-way ANOVA analysis with Turkey's post-test, using GraphPad Prism (version 4.0) software. A value of $\mathrm{p}<0.05$ was considered to indicate a statistically significant difference.

\section{Results}

Effect of heparin in B6FS fibrosarcoma cell functions. Initially, we examined the effects of UFH and LMWH on FN-dependent B6FS cell adhesion. As shown in Fig. 1A, both UFH and LMWH enhanced B6FS cell adhesion $(\mathrm{p}<0.01, \mathrm{p}<0.05)$; the maximal effect being evident at the concentration of $10 \mu \mathrm{g} / \mathrm{ml}$. Of note, the molecular weight of the heparin preparations did not modify their effects on cellular function. Thus, UFH and
LMWH had the same promoting effect on B6FS cell adhesion. This suggests that the effects of heparin are attributed to its oligosaccharide structure.

In continuation, we analyzed the effects of heparin on B6FS fibrosarcoma cell migration. Subsequent to pre-treatment with $\mathrm{UFH}$ and LMWH $(10 \mu \mathrm{g} / \mathrm{ml})$ an enhancement of fibrosarcoma cell migration was observed ( $\mathrm{p}<0.05$; Fig. $1 \mathrm{~B}$ and $\mathrm{C}$ ). To exclude false-positive results due to traces of heparin-binding growth factors, heat treatment was applied for the utilized heparin preparation. The effects of heparin on cell adhesion/migration were not affected by heat treatment (data not shown).

The participation of FAK is necessary for heparin-induced cell adhesion. FAK is a $125-\mathrm{kDa}$ cytoplasmic tyrosine kinase protein which is primarily positioned at adhesion sites and plays a key role in the processes of cell adhesion and migration (44). Importantly, FAK expression has been shown to be closely associated with (even in early reports) aggressive cancer behavior (45). To examine the putative participation 

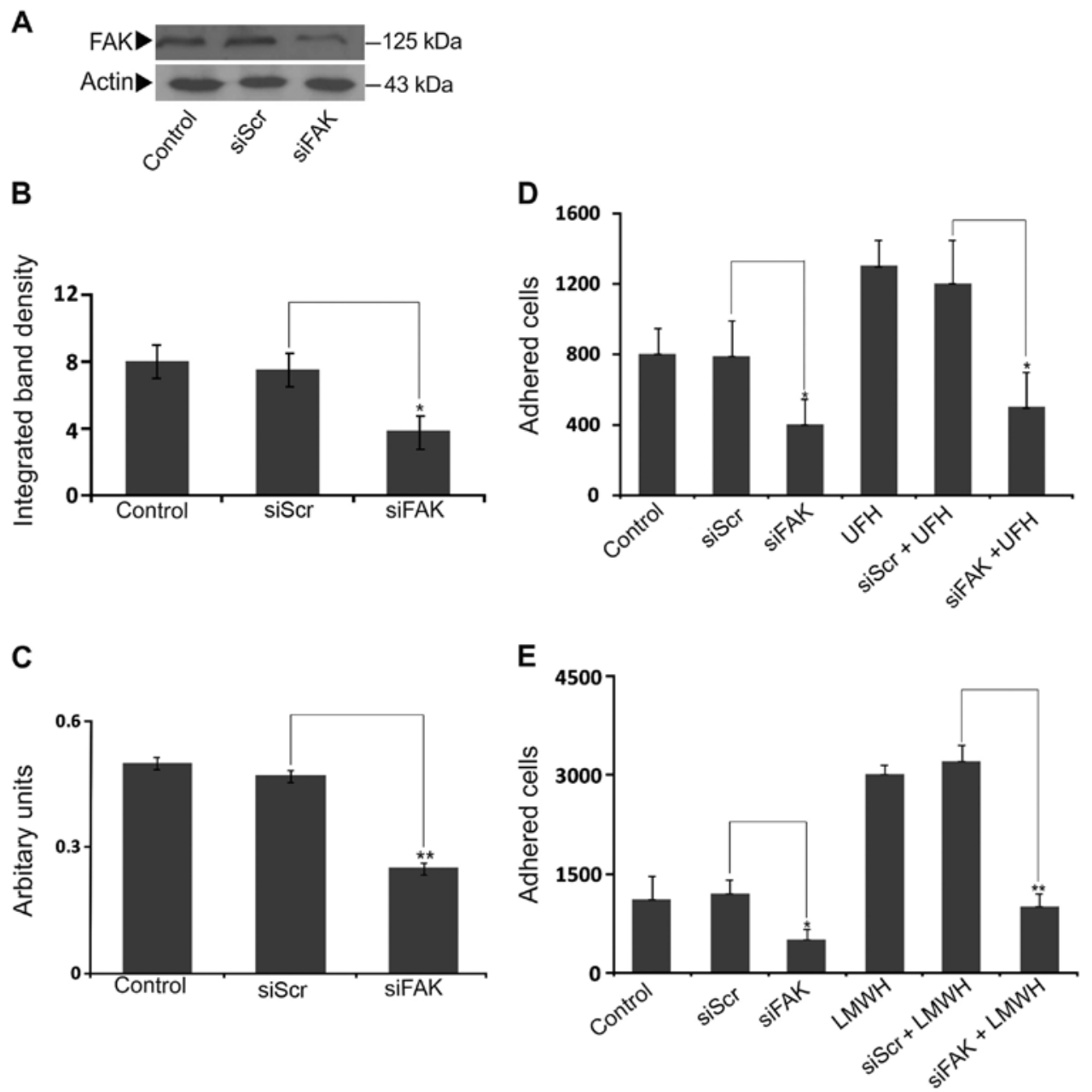

Figure 2. Effect of focal adhesion kinase (FAK) on unfractionated heparin (UFH) and low-molecular-weight heparin (LMWH)-dependent B6FS cell adhesion. (A) B6FS cells were transfected with FAK short interfering RNA (siFAK), whereas scramble RNA (siScr) was used as a negative control. The cells were cultured for $48 \mathrm{~h}$ prior to harvesting. Representative blot of FAK protein (125 kDa band) is presented; (B) FAK protein bands were densitometrically analyzed and adjusted against actin; (C) B6FS cells were transfected with siFAK with the use of siScr as a negative control. The cells were cultured for $48 \mathrm{~h}$ prior to harvesting and the FAK expression level was verified by real-time PCR. Subsequenlty, $24 \mathrm{~h}$ after transfection, the B6FS cells were treated with (D) UFH (10 $\mu \mathrm{g} / \mathrm{ml})$ and (E) LMW heparin $(10 \mu \mathrm{g} / \mathrm{ml})$ for $48 \mathrm{~h}$ prior ot harvesting and reseeding for $1 \mathrm{~h}$ on 96 -well plates coated with fibronectin. The number of attached cells was determined using thefluometric CyQUANT assay kit. The results represent the average of 3 separate experiments in triplicate. The means \pm standard error of the mean are plotted. $\mathrm{p}<0.05$ and ${ }^{* *} \mathrm{p}<0.01$, indicate statistically significant differences.

of FAK in heparin-dependent adhesion, the B6FS cells were transfected with siRNA specific for the FAK gene as previously described (41). This approach resulted in an efficient downregulation of FAK both at the mRNA $(\mathrm{p}<0.01)$ and protein level $(\mathrm{p}<0.05)$ (Fig. 2A-C). Our results demonstrated that the FAK-deficient cells exhibited a marked decrease in their basal level ability to adhere to the FN substrate ( $<<0.05$; Fig. 2D). Importantly, both the UFH and LMWH stimulatory effects on B6FS cell adhesion were abolished in the FAK-deficient cells $(\mathrm{p}<0.05$ and $\mathrm{p}<0.01$, respectively) (Fig. 2D and $\mathrm{E}$ ). Therefore, the effect of heparin on fibrosarcoma cell adhesion was FAK-dependent.

Effect of heparin on FAK activation. Heparin has been shown to antagonize the function of integrin adhesion receptors (46), which trigger FAK clustering (47), and to have an effect on FAK expression and activation $(33,34)$. Thus, we investigated the possible role of heparin in FAK expression and activation. To this end, the heparin-treated B6FS cell extracts were probed with antibodies against FAK and p-FAK. As shown in Fig. 3A and B, both UFH and LMWH significantly activated FAK (Y397) at $10 \mu \mathrm{g} / \mathrm{ml}$, whereas no effect of heparin on total FAK protein expression was evident (Fig. 3A and B).

NF- $\kappa B$ has been previoulsy demonstrated to stimulate FAK promoter activity and upregulation (41). Heparin has been suggested to modulate NF- $\kappa \mathrm{B}$ translocation to the nucleus and its transcriptional activity (48). In this study, we examined the possible role of NF- $\mathrm{KB}$ in heparin-induced FAK activation by using a specific antibody for the p65 subunit of NF- $\mathrm{KB}$. As shown in Fig. 3C and D, UFH and LMWH did not affect the protein expression of the p65 subunit of NF- $\kappa$ B. Thus, p65 does not participate in the heparin-induced upregulation of FAK (Fig. 3C and D).

Heparin affects cytoskeleton organization in B6FS cells. The phenotype of cancer cells is directly associated with their adhesive and migratory properties, which are of utmost importance for the process of cancer metastasis (49). FAK, has 
A

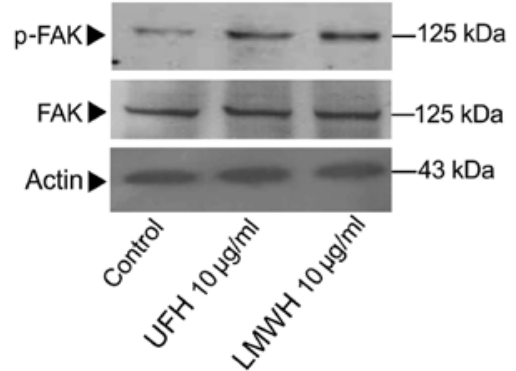

B

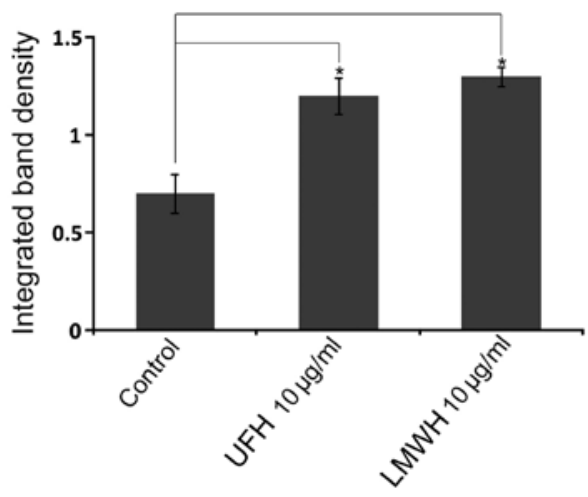

C

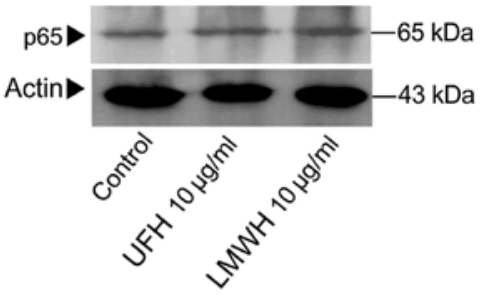

D

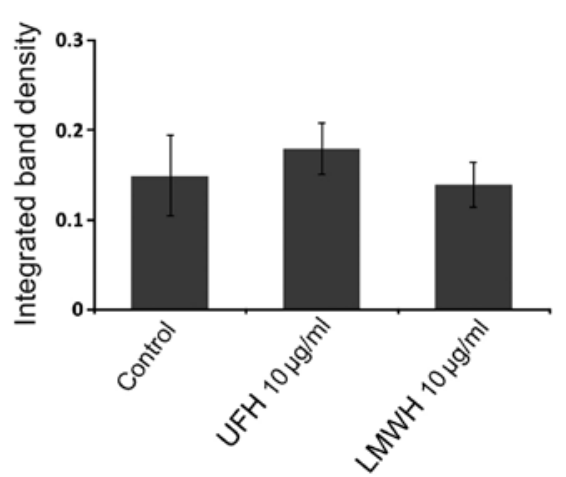

Figure 3. Role of unfractionated heparin (UFH) and low-molecular-weight heparin (LMWH) in focal adhesion kinase (FAK) activation. (A) B6FS cells were treated with UFH $(10 \mu \mathrm{g} / \mathrm{ml})$ and LMWH $(10 \mu \mathrm{g} / \mathrm{ml})$ for $48 \mathrm{~h}$ prior to harvesting. Representative blots of FAK and p-FAK protein (125 kDa) are presented; (C) B6FS cells were treated with UFH $(10 \mu \mathrm{g} / \mathrm{ml})$ and LMWH $(10 \mu \mathrm{g} / \mathrm{ml})$ for $48 \mathrm{~h}$ prior to harvesting. Representative blot of nuclear factor- $\mathrm{\kappa B}(\mathrm{NF}-\mathrm{kB})(65 \mathrm{kDa})$ is presented; (D) NF- $\mathrm{kB}(65 \mathrm{kDa})$ protein band was densitometrically analyzed and adjusted against actin. The results represent the average of 3 separate experiments in triplicate. The means \pm standard error of the mean are plotted. ${ }^{p}<0.05$, indicates a statistically significant difference
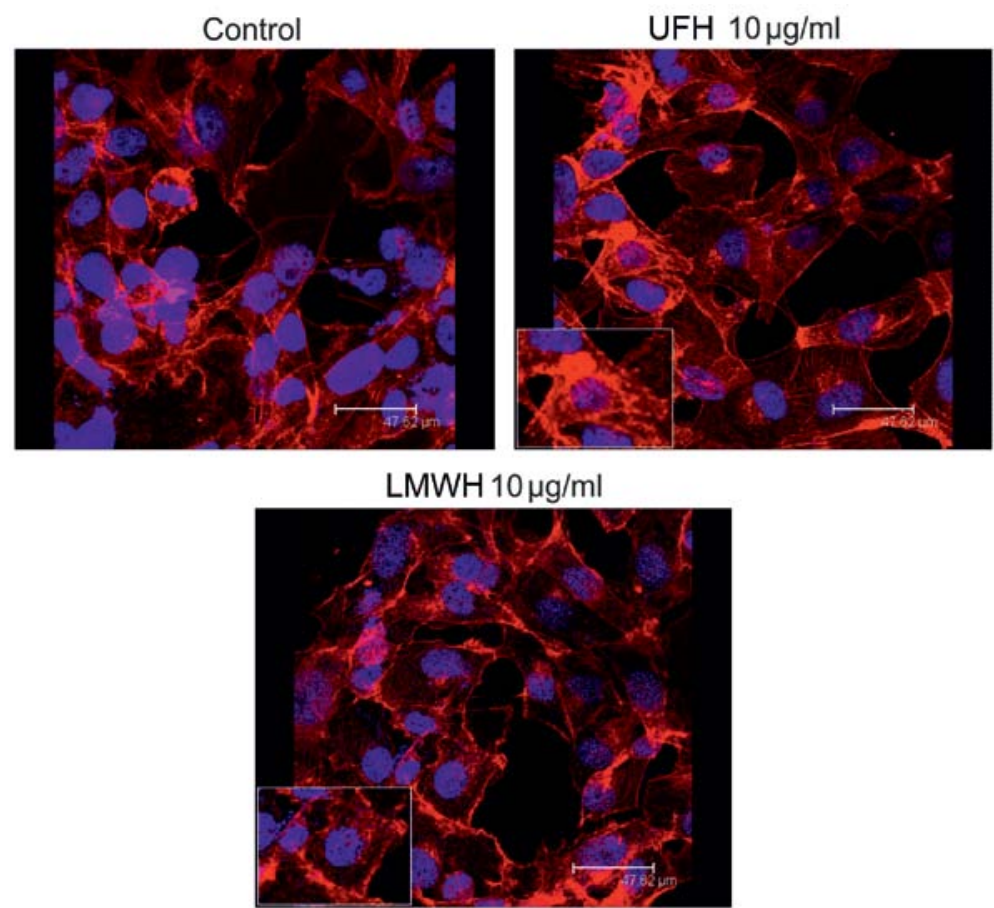

Figure 4. Role of unfractionated heparin (UFH) and low-molecular-weight heparin (LMWH) on actin polymerization. B6FS cells were treated with UFH and LMWH $(10 \mu \mathrm{g} / \mathrm{ml})$ for $48 \mathrm{~h}$, were seeded onto round coverslips, fixed, permeabilized and then stained then stained using phalloidin to visualize the actin filaments (red color). The nuclei were stained using TO-PRO-3. The signals against phalloidin and TO-PRO-3 were superimposed. Slides were analyzed by confocal microscopy, and images were acquired at a magnification of $x 40$.

been postulated as the key conduit point which regulates the flow of signals from the ECM to the actin cytoskeleton (50). In this study, we investigated the possible effect of heparin on actin cytoskeleton organization in B6FS fibrosarcoma cells. To this end, rhodamine-conjugated phalloidin staining was used. The results of confocal miscroscopy indicated that B6FS cell 


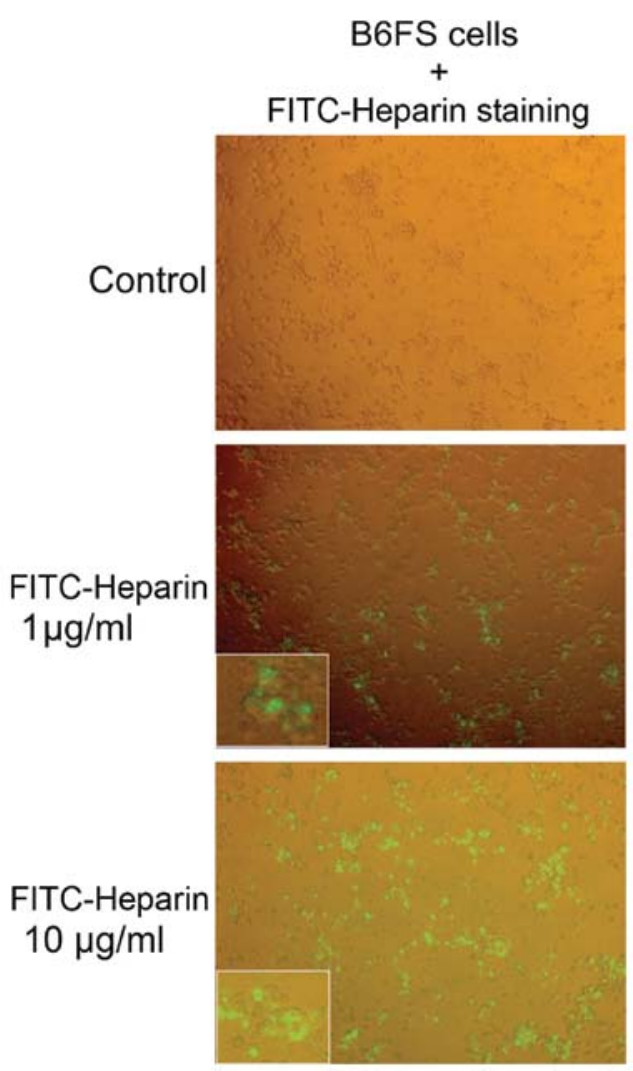

Figure 5. Internalization of fluorescein isothiocyanate (FITC)-conjugated unfractionated heparin (FITC-Heparin). B6FS cells were incubated with 1 and $10 \mu \mathrm{g} / \mathrm{ml}$ FITC-Heparin) and heparin internalization was visualized at $24 \mathrm{~h}$ at a magnification of x 20 . Cells incubated in $0 \%$ RPMI (control) were utilized as negative controls.

actin cytoskeleton organization was enhanced. Thus, both the HMW- and LMWH-treated cells were found to have the fully spread, adhesive phenotype with the cells being stretched by the tensile forces of actin stress fibers (Fig. 4).

Heparin internalization in B6FS fibrosarcoma cells. In continuation, we hypothesized that heparin affects fibrosarcoma cell motility and cell attachment through its internalization. Indeed, the cellular internalization of heparin has been demonstrated in previous studies $(51,52)$. In this study, FITC-Heparin was utilized to investigate the internalization of heparin in B6FS fibrosarcoma cells. As shown in Fig. 5, FITCHeparin was taken up by the B6FS cells in a dose-dependent manner, with the majority of cells exhibiting strong staining. The results of immunoflourescence demonstrated that FITC-Heparin was located, not only in the cytoplasmic region, but also in the nucleus of fibrosarcoma cells.

Effect of cell-associated HS chains on B6FS cell adhesion. HS exhibits structural similarities with heparin, but does not have as many 'highly sulfated' sequences consisting of tri-sulfated disaccharide units, which are sequences with the highest binding affinity to heparin/HS-binding proteins (53). Biochemical analyses of the metabolically [3H]-labeled $\mathrm{CS} / \mathrm{DS} / \mathrm{HS} / \mathrm{PGs}$ produced by the B6FS cells demonstrated that the HS amount was $63.1 \%$ of the total B6FS cell-associated GAGs (data not shown). Therefore, we examined the possible
A

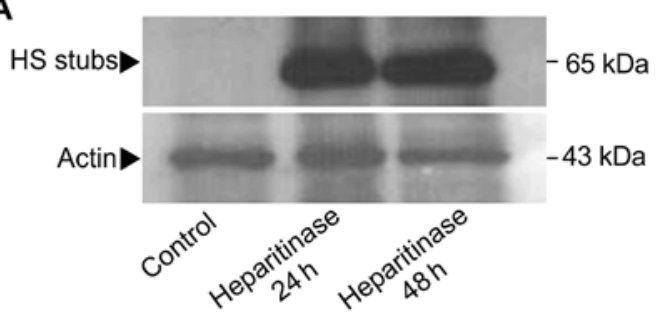

B

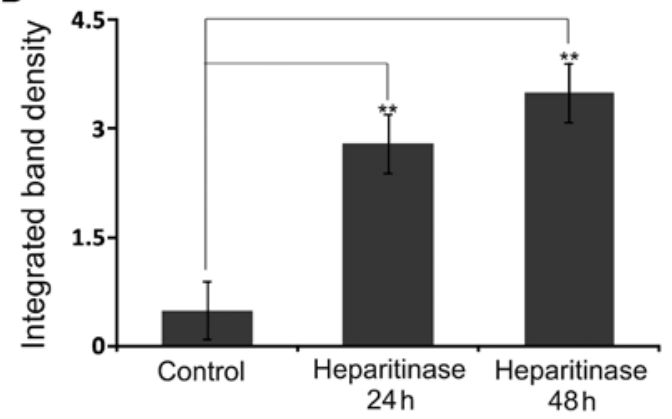

C

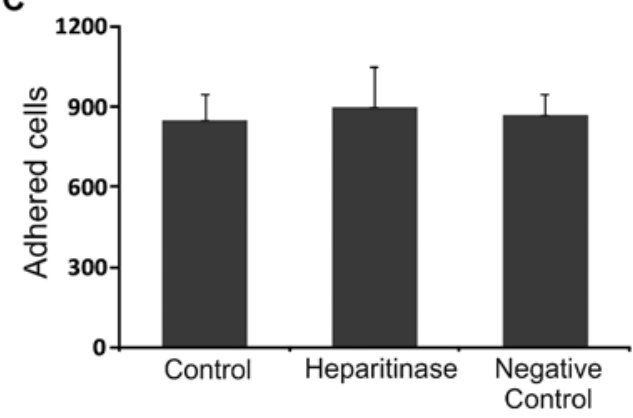

Figure 6. Role of heparan sulfate (HS) chains on B6FS cell adhesion. (A) B6FS cell extracts, treated with heparitinase $(0.001 \mathrm{U} / \mathrm{ml})$ for 0,24 and $48 \mathrm{~h}$, were immunoblotted with the monoclonal antibody $3 \mathrm{G} 10$ which recognizes a neoepitope generated by heparitinase digestion (lane 1, untreated cells; lane 2, 24-h heparitinase-treated cells; lane 3, 48-h heparitinase-treated cells. Representative blot of HS stubs is presented; (B) HS epitope band band was densitometrically analyzed and adjusted against actin; (C) B6FS cells were treated with heparitinase $(0,001 \mathrm{U})$ for $48 \mathrm{~h}$ prior to harvesting and reseeding for $1 \mathrm{~h}$ on 96 -well plates coated with fibronectin. The number of attached cells was determined using the fluometric CyQUANT assay kit. The results represent the average of 3 separate experiments in triplicate. The means \pm standard error of the mean are plotted. ${ }^{* *} \mathrm{p}<0.01$, indicates a statistically significant difference.

involvement of endogenous HS chains on B6FS cell adhesion. Initially, treatment of the cells with heparitinase and concomitant blotting with the monoclonal antibody $3 \mathrm{G} 10$, which recognizes a neoepitope generated by heparitinase digestion, demonstrated an efficient removal of HS chains at the $24 \mathrm{~h}$ time point (Fig. 6A and B). The specific digestion of cell-associated HS with heparitinase did not affect their adhesion to FN (Fig. 6C). These results suggest that B6FS cell adhesion is independent of their cell-associated HS content.

\section{Discussion}

In the present study, the effects of UFH and LMWH on fibrosarcoma cell motility functions were examined. We demonstrated that both heparin preparations affected fibrosarcoma cell motility and adhesion. The stimulatory effects of both UFH 
and LMWH on B6FS cell adhesion were FAK-dependent and resulted in actin cytoskeleton reorganization.

Fibrosarcoma is a tumor of mesenchymal origin that is mostly composed of transformed fibroblasts and abundant is in ECM microenvironment $(2,54)$. The B6FS cell line originates from a poorly differentiated fibrosarcoma (40). In poorly differentiated tumors, cancer cells are characterized by scant phenotypic similarity with cells of origin, mild pleomorphism, as well as intense mitotic activity $(55,56)$. It is noteworthy that fibrosarcoma is a particularly heterogeneous tumor type, taking into account morphology, differentiation and behavior (57).

In this study, we demonstrated a promoting effect of UFH and LMWH on the motility of B6FS cells. Specifically, both UFH and LMWH were found to enhance cell adhesion onto FN, as well as the migration of B6FS fibrosarcoma cells. Heparin and the closely resembling HS chains, via the activation of key cell signaling pathways (for fibrosarcoma cells), act as extracellular regulators for many cell functions $(5,58,59)$. Previously, we demonstrated a negative regulatory effect of LMWH on melanoma cell adhesion and migration via the PKC $\alpha / J N K$ signaling pathway (34). Furthermore, LMWH was found to inhibit the proliferation, migration, invasion and the induction of lung metastases of HT1080 fibrosarcoma cells, through a blockade of the RAGE axis (32). Likewise, in the present study, we examined the mechanisms of action of heparin in B6FS cells by focusing on FAK (60). FAK, as its name implies, is a key constituent of the focal adhesion complex, which is an actin-based anchoring junction limited to the cell-ECM interface in mammalian tissues. It is used by motile cells, such as fibroblasts and metastatic cancer cells for their attachment and movement under physiological or pathological conditions (61). By generating FAK-deficient cells, as previously described $(33,41)$ we demonstrated that the effects of UFH and LMWH on B6FS cell adhesion were FAK-dependent. As regards the effect of heparin on cell adhesion, in other cell models, it has been shown that the interaction of heparin activates integrin and results in the tyrosine-phosphorylation of focal adhesion-associated proteins, such as FAK, Src and paxillin in endothelial cells (62). On the other hand, heparin has been shown to block osteoblast adhesion onto osteoactivin in an FAK/ERK-dependent manner (63). In the present study, however, both UFH and LMWH were was found to enhance FAK (Y397) phosphorylation in B6FS fibrosarcoma cells. FAK activation is closely associated with actin cytoskeleton organization. Importantly, both heparin preparations were demonstrated to induce morphological changes in the B6FS cell actin cytoskeleton. Indeed, actin polymerization results in the formation of the actin stress fibers, which are necessary for efficient cell motility functions. Treatment of fibrosarcoma cells with both UFH and LMWH enhanced the formation of actin filaments and induced the well 'spread' migratory active phenotype. This effect of heparin on the organization of the cytoskeleton is well correlated with the heparin-dependent enhancement of B6FS cell adhesion and migration.

The internalization of heparin has been demonstrated in various cell models. Thus, heparin stabilizes lens epithelium-derived growth factor (LEDGF) and facilitates its translocation from the ECM to the nucleus (64). In a murine macrophage cell line, heparin was found to initiate the phogocytosis of gelatin-latex particles (65), whereas we previously demonstrated an internalization of UFH in melanoma cells (33). In continuation, in the present study, we investigated the putative internalization of heparin in the B6FS cell model utilizing FITC-Heparin. This approach showed a dose-dependent internalization of FITC-Heparin and its subsequent localization into the B6FS cell cytoplasm and nucleus. Importantly, other authors have provided data which showed the heparin nuclear localization and regulation of gene expression of several cell types $(66,67)$, even though the mechanism of heparin uptake remains unspecified (48). Thus, heparin is suggested to regulate the transactivation of transcription factors, such as Jun/c-Fos/AP-1 (68) and to inhibit NF- $\mathrm{KB}$ transcriptional activity (48). Moreover, NF- $\mathrm{KB}$ was suggested to stimulate FAK activation (41). In the B6FS cells, no effect of heparin on NF- $\mathrm{kB}$, subunit $\mathrm{p} 63$, transactivation was evident and the intracellular mechanism of heparin action resulting in FAK/actin cytoskeleton-dependent enhanced adhesion and migration requires further study.

In the present study, the enzymatic cleavage of endogenous HS chains did not affect the adhesion of B6FS cell line. These data suggests that the exogenous addition of heparin specifically activates signaling pathways responsible for the promotion of cell adhesion and migration and highlights the putative role of heparin/HS content of the cancer microenvironment. The effects of heparin seem to be tissue and cell line- specific. Thus, studies have suggested that heparin exerts an inhibitory effect on both cancer and normal cell proliferation $(21-23,28)$. On the other hand, a dose-dependent stimulatory role of heparin on the proliferation of HT29, SW1116 and HCT116 human colon cancer cells, with no involvement of endogenous HS chains was proposed (27).

In this study, we report that both UFH and LMWH through a FAK/actin cytoskeleton axis, enhance the adhesion and migration of B6FS fibrosarcoma cells. The responsiveness of fibrosarcoma cell motility to the exogenous heparin/HS content of the cancer microenvironment may play a role in their ability to metastasize. The exact mechanisms of action of heparin require further investigation, which is currently under way in our laboratories.

\section{References}

1. Meric F, Hess KR, Varma DG, Hunt KK, Pisters PW, Milas KM, Patel SR, Benjamin RS, Plager C, Papadopoulos NE, et al: Radiographic response to neoadjuvant chemotherapy is a predictor of local control and survival in soft tissue sarcomas. Cancer 95: 1120-1126, 2002.

2. Nedea EA and DeLaney TF: Sarcoma and skin radiation oncology. Hematol Oncol Clin North Am 20: 401-429, 2006.

3. Jemal A, Siegel R, Ward E, Murray T, Xu J and Thun MJ: Cancer statistics, 2007. CA Cancer J Clin 57: 43-66, 2007.

4. Linhardt RJ: 2003 Claude S. Hudson Award address in carbohydrate chemistry. Heparin: Structure and activity. J Med Chem 46: 2551-2564, 2003.

5. Engelberg H: Actions of heparin that may affect the malignant process. Cancer 85: 257-272, 1999.

6. Vlodavsky I and Friedmann Y: Molecular properties and involvement of heparanase in cancer metastasis and angiogenesis. J Clin Invest 108: 341-347, 2001.

7. Tyagi SC, Kumar S and Katwa L: Differential regulation of extracellular matrix metalloproteinase and tissue inhibitor by heparin and cholesterol in fibroblast cells. J Mol Cell Cardiol 29: 391-404, 1997.

8. Smorenburg SM and Van Noorden CJ: The complex effects of heparins on cancer progression and metastasis in experimental studies. Pharmacol Rev 53: 93-105, 2001. 
9. Elias EG, Shukla SK and Mink IB: Heparin and chemotherapy in the management of inoperable lung carcinoma. Cancer 36: 129-136, 1975.

10. Kakkar AK and Macbeth F: Antithrombotic therapy and survival in patients with malignant disease. Br J Cancer 102 (Suppl 1): S24-S29, 2010

11. Malavaki CJ, Theocharis AD, Lamari FN, Kanakis I, Tsegenidis T, Tzanakakis GN and Karamanos NK: Heparan sulfate: Biological significance, tools for biochemical analysis and structural characterization. Biomed Chromatogr 25: 11-20, 2011.

12. Karamanos NK and Tzanakakis GN: Glycosaminoglycans: From 'cellular glue' to novel therapeutical agents. Curr Opin Pharmacol 12: 220-222, 2012.

13. Halkin H, Goldberg J, Modan M and Modan B: Reduction of mortality in general medical in-patients by low-dose heparin prophylaxis. Ann Intern Med 96: 561-565, 1982.

14. Chahinian AP, Propert KJ, Ware JH, Zimmer B, Perry MC, Hirsh V, Skarin A, Kopel S, Holland JF, Comis RL, et al: A randomized trial of anticoagulation with warfarin and of alternating chemotherapy in extensive small-cell lung cancer by the Cancer and Leukemia Group B. J Clin Oncol 7: 993-1002, 1989.

15. Hettiarachchi RJ, Smorenburg SM, Ginsberg J, Levine M, Prins MH and Büller HR: Do heparins do more than just treat thrombosis? The influence of heparins on cancer spread. Thromb Haemost 82: 947-952, 1999.

16. von Tempelhoff GF, Harenberg J, Niemann F, Hommel G Kirkpatrick CJ and Heilmann L: Effect of low molecular weight heparin (Certoparin) versus unfractionated heparin on cancer survival following breast and pelvic cancer surgery: A prospective randomized double-blind trial. Int J Oncol 16: 815-824, 2000.

17. Mousa SA and Mohamed S: Anti-angiogenic mechanisms and efficacy of the low molecular weight heparin, tinzaparin: Anti-cancer efficacy. Oncol Rep 12: 683-688, 2004.

18. Ettelaie C, Fountain D, Collier ME, Beeby E, Xiao YP and Maraveyas A: Low molecular weight heparin suppresses tissue factor-mediated cancer cell invasion and migration in vitro. Exp Ther Med 2: 363-367, 2011.

19. Alyahya R, Sudha T, Racz M, Stain SC and Mousa SA: Anti-metastasis efficacy and safety of non-anticoagulant heparin derivative versus low molecular weight heparin in surgical pancreatic cancer models. Int J Oncol 46: 1225-1231, 2015 .

20. Tiozzo R, Cingi MR, Pietrangelo A, Albertazzi L, Calandra S and Milani MR: Effect of heparin-like compounds on the in vitro proliferation and protein synthesis of various cell types. Arzneimittelforschung 39: 15-20, 1989

21. Au YP, Kenagy RD, Clowes MM and Clowes AW: Mechanisms of inhibition by heparin of vascular smooth muscle cell proliferation and migration. Haemostasis 23 (Suppl 1): 177-182, 1993.

22. Bennett MR, Evan GI and Newby AC: Deregulated expression of the c-myc oncogene abolishes inhibition of proliferation of rat vascular smooth muscle cells by serum reduction, interferon-gamma, heparin, and cyclic nucleotide analogues and induces apoptosis. Circ Res 74: 525-536, 1994.

23. Miralem T, Wang A, Whiteside CI and Templeton DM: Heparin inhibits mitogen-activated protein kinase-dependent and -independent c-fos induction in mesangial cells. J Biol Chem 271: 17100-17106, 1996.

24. Nikitovic D, Assouti M, Sifaki M, Katonis P, Krasagakis K Karamanos NK and Tzanakakis GN: Chondroitin sulfate and heparan sulfate-containing proteoglycans are both partners and targets of basic fibroblast growth factor-mediated proliferation in human metastatic melanoma cell lines. Int J Biochem Cell Biol 40: 72-83, 2008

25. Nikitovic D, Zafiropoulos A, Tzanakakis GN, Karamanos NK and Tsatsakis AM: Effects of glycosaminoglycans on cell proliferation of normal osteoblasts and human osteosarcoma cells depend on their type and fine chemical compositions. Anticancer Res 25: 2851-2856, 2005.

26. Chatzinikolaou G, Nikitovic D, Asimakopoulou A, Tsatsakis A, Karamanos NK and Tzanakakis GN: Heparin - a unique stimulator of human colon cancer cells' growth. IUBMB Life 60: 333-340, 2008

27. Chatzinikolaou G, Nikitovic D, Berdiaki A, Zafiropoulos A, Katonis P, Karamanos NK and Tzanakakis GN: Heparin regulates colon cancer cell growth through p38 mitogen-activated protein kinase signalling. Cell Prolif 43: 9-18, 2010.
28. Fthenou E, Zafiropoulos A, Tsatsakis A, Stathopoulos A, Karamanos NK and Tzanakakis GN: Chondroitin sulfate A chains enhance platelet derived growth factor-mediated signalling in fibrosarcoma cells. Int J Biochem Cell Biol 38: 2141-2150, 2006.

29. Boeryd B: Action of heparin and plasminogen inhibitor (EACA) on metastatic tumour spread in an isologous system. Acta Pathol Microbiol Scand 65: 395-404, 1965.

30. Hagmar B and Norrby K: Evidence for effects of heparin on cell surfaces influencing experimental metastases. International journal of cancer Int J Cancer 5: 72-84, 1970.

31. Maat B: Extrapulmonary colony formation after intravenous injection of tumour cells into heparin-treated animals. Br J Cancer 37: 369-376, 1978.

32. Takeuchi A, Yamamoto Y, Munesue S, Harashima A, Watanabe T, Yonekura H, Yamamoto $\mathrm{H}$ and Tsuchiya H: Low molecular weight heparin suppresses receptor for advanced glycation end products-mediated expression of malignant phenotype in human fibrosarcoma cells. Cancer Sci 104: 740-749, 2013.

33. Chalkiadaki G, Nikitovic D, Berdiaki A, Katonis P, Karamanos NK and Tzanakakis GN: Heparin plays a key regulatory role via a p53/FAK-dependent signaling in melanoma cell adhesion and migration. IUBMB Life 63: 109-119, 2011.

34. Chalkiadaki G, Nikitovic D, Katonis P, Berdiaki A, Tsatsakis A, Kotsikogianni I, Karamanos NK and Tzanakakis GN: Low molecular weight heparin inhibits melanoma cell adhesion and migration through a $\mathrm{PKCa} / \mathrm{JNK}$ signaling pathway inducing actin cytoskeleton changes. Cancer Lett 312: 235-244, 2011

35. Pankov R and Yamada KM: Fibronectin at a glance. J Cell Sci 115: 3861-3863, 2002.

36. Clark EA, Golub TR, Lander ES and Hynes RO: Genomic analysis of metastasis reveals an essential role for RhoC. Nature 406: $532-535,2000$.

37. Inoue T, Nabeshima K, Shimao Y, Kataoka H and Koono M: Modulation of fibronectin synthesis by cancer cell-fibroblast interaction. Int J Oncol 9: 721-730, 1996.

38. Mytilinaiou M, Bano A, Nikitovic D, Berdiaki A, Voudouri K, Kalogeraki A, Karamanos NK and Tzanakakis GN: Syndecan-2 is a key regulator of transforming growth factor beta $2 / \mathrm{Smad} 2$-mediated adhesion in fibrosarcoma cells. IUBMB Life 65: 134-143, 2013.

39. Kouvidi K, Berdiaki A, Nikitovic D, Katonis P, Afratis N, Hascall VC, Karamanos NK and Tzanakakis GN: Role of receptor for hyaluronic acid-mediated motility (RHAMM) in low molecular weight hyaluronan (LMWHA)-mediated fibrosarcoma cell adhesion. J Biol Chem 286: 38509-38520, 2011.

40. Thurzo V, Popovic M, Matoska J, Blasko M, Grófová M, Lizonová A and Steno M: Human neoplastic cells in tissue culture: Two established cell lines derived from giant cell tumor and fibrosarcoma. Neoplasma 23: 577-587, 1976.

41. Hong IK, Jin YJ, Byun HJ, Jeoung DI, Kim YM and Lee H: Homophilic interactions of Tetraspanin CD151 up-regulate motility and matrix metalloproteinase- 9 expression of human melanoma cells through adhesion-dependent c-Jun activation signaling pathways. J Biol Chem 281: 24279-24292, 2006

42. Karamanos NK, Axelsson S, Vanky P, Tzanakakis GN and Hjerpe A: Determination of hyaluronan and galactosaminoglycan disaccharides by high-performance capillary electrophoresis at the attomole level. Applications to analyses of tissue and cell culture proteoglycans. J Chromatogr A 696: 295-305, 1995.

43. Karamanos NK, Vanky P, Tzanakakis GN, Tsegenidis T and Hjerpe A: Ion-pair high-performance liquid chromatography for determining disaccharide composition in heparin and heparan sulphate. J Chromatogr A 765: 169-179, 1997.

44. Schaller MD, Borgman CA, Cobb BS, Vines RR, Reynolds AB and Parsons JT: pp125FAK a structurally distinctive protein-tyrosine kinase associated with focal adhesions. Proc Natl Acad Sci USA 89: 5192-5196, 1992.

45. Weiner TM, Liu ET, Craven RJ and Cance WG: Expression of focal adhesion kinase gene and invasive cancer. Lancet 342 : 1024-1025, 1993.

46. Fritzsche J, Simonis D and Bendas G: Melanoma cell adhesion can be blocked by heparin in vitro: Suggestion of VLA-4 as a novel target for antimetastatic approaches. Thromb Haemost 100: 1166-1175, 2008.

47. Moyano JV,Maqueda A,Albar JP and Garcia-Pardo A: A synthetic peptide from the heparin-binding domain III (repeats III4-5) of fibronectin promotes stress-fibre and focal-adhesion formation in melanoma cells. Biochem J 371: 565-571, 2003. 
48. Dudás J, Ramadori G, Knittel T, Neubauer K, Raddatz D, Egedy K and Kovalszky I: Effect of heparin and liver heparan sulphate on interaction of HepG2-derived transcription factors and their cis-acting elements: Altered potential of hepatocellular carcinoma heparan sulphate. Biochem J 350: 245-251, 2000.

49. Geiger B and Yamada KM: Molecular architecture and function of matrix adhesions. Cold Spring Harb Perspect Biol 3: 3, 2011.

50. Parsons JT, Martin KH, Slack JK, Taylor JM and Weed SA: Focal adhesion kinase: A regulator of focal adhesion dynamics and cell movement. Oncogene 19: 5606-5613, 2000.

51. Castellot JJ Jr, Wong K, Herman B, Hoover RL, Albertini DF, Wright TC, Caleb BL and Karnovsky MJ: Binding and internalization of heparin by vascular smooth muscle cells. J Cell Physiol 124: 13-20, 1985.

52. Bârzu T, Pascal M, Maman M, Roque C, Lafont F and Rousselet A: Entry and distribution of fluorescent antiproliferative heparin derivatives into rat vascular smooth muscle cells: Comparison between heparin-sensitive and heparin-resistant cultures. J Cell Physiol 167: 8-21, 1996.

53. Casu B and Lindahl U: Structure and biological interactions of heparin and heparan sulfate. Adv Carbohydr Chem Biochem 57: 159-206, 2001.

54. Shrivastava S, Nayak SK, Nayak P and Sahu S: Fibrosarcoma of maxilla: A rare case report. J Oral Maxillofac Pathol 20: 162, 2016.

55. Thway K, Robertson D, Jones RL, Selfe J, Shipley J, Fisher C and Isacke CM: Endosialin expression in soft tissue sarcoma as a potential marker of undifferentiated mesenchymal cells. $\mathrm{Br} \mathbf{J}$ Cancer: Jul 19, 2016 (Epub ahead of print).

56. Noujaim J, Thway K, Sheri A, Keller C and Jones RL: Histology-Driven Therapy: The Importance of Diagnostic Accuracy in Guiding Systemic Therapy of Soft Tissue Tumors. Int J Surg Pathol 24: 5-15, 2016.

57. Blizniukov OP and Zamogil'naia IaA: Pleomorphic fibrosarcoma Vopr Onkol 58: 54-60, 2012 (In Russian).

58. Rabenstein DL: Heparin and heparan sulfate: Structure and function. Nat Prod Rep 19: 312-331, 2002.
59. Chen Q, Zhou Z, Shan L, Zeng H, Hua Y and Cai Z: The importance of Src signaling in sarcoma. Oncol Lett 10: 17-22, 2015.

60. Hauck CR, Hsia DA and Schlaepfer DD: The focal adhesion kinase - a regulator of cell migration and invasion. IUBMB Life 53: 115-119, 2002.

61. Hall JE, Fu W and Schaller MD: Focal adhesion kinase: Exploring Fak structure to gain insight into function. Int Rev Cell Mol Biol 288: 185-225, 2011.

62. Medeiros VP, Paredes-Gamero EJ, Monteiro HP, Rocha HA, Trindade ES and Nader HB: Heparin-integrin interaction in endothelial cells: Downstream signaling and heparan sulfate expression. J Cell Physiol 227: 2740-2749, 2012.

63. Moussa FM, Hisijara IA, Sondag GR, Scott EM, Frara N, Abdelmagid SM and Safadi FF: Osteoactivin promotes osteoblast adhesion through HSPG and $\alpha v \beta 1$ integrin. J Cell Biochem 115: 1243-1253, 2014

64. Fatma N, Singh DP, Shinohara T and Chylack LT Jr: Heparin's roles in stabilizing, potentiating, and transporting LEDGF into the nucleus. Invest Ophthalmol Vis Sci 41: 2648-2657, 2000.

65. van de Water L III, Schroeder S, Crenshaw EB III and Hynes RO: Phagocytosis of gelatin-latex particles by a murine macrophage line is dependent on fibronectin and heparin. J Cell Biol 90: 32-39, 1981

66. Kovalszky I, Dudás J, Oláh-Nagy J, Pogány G, Töváry J, Timár J, Kopper L, Jeney A and Iozzo RV: Inhibition of DNA topoisomerase I activity by heparan sulfate and modulation by basic fibroblast growth factor. Mol Cell Biochem 183: 11-23, 1998.

67. Timar $\mathrm{J}$ and Paterson H: Localization and production of proteoglycans by HT1080 cell lines with altered N-ras expression. Cancer Lett 53: 145-150, 1990.

68. Busch SJ, Martin GA, Barnhart RL, Mano M, Cardin AD and Jackson RL: Trans-repressor activity of nuclear glycosaminoglycans on Fos and Jun/AP-1 oncoprotein-mediated transcription. J Cell Biol 116: 31-42, 1992. 